\title{
Friedreich's Ataxia: Observations with Q and G Banding of Human Chromosomes
}

\author{
M. CADOTTE, A. BARBEAU AND G. BRETON
}

SUMMARY: No chromosomal anomaly was found in 15 cases of typical Friedreich's ataxia and three cases of atypical recessive ataxia studied with $Q$ and $G$ banding techniques. No difference between frequency of chromosomes gaps or breakages was noted amongst patients with Friedreich's ataxia and controls.

RÉSUMÉ: Parmi 15 cas d'ataxie de Friedreich "typique" et 3 d'ataxie récessive atypique, nous n'avons trouvé aucune anomalie chromosomale en employant les nouvelles techniques d'identification des bandes $Q$ et $G$. II n'y avait aucune différence entre la fréquence des cassures ou des espaces notée chez les ataxiques ou chez les controles.
From the Hôpital Hôtel-Dieu de Montréal, and the Clinical Research Institute of Montreal.

Reprint requests for the complete supplement on Friedreich's ataxia to: Dr. André Barbeau, Clinical Research Institute of Montreal, 110 Pine Avenue West, Montreal, H2W 1R7 Quebec, Canada.

\section{INTRODUCTION}

Some cytogenetic studies were included in a protocol of investigation of Friedreich's ataxia. The quinacrine mustard fluorescence technique of Caspersson et al. (1970), as well as the $\mathrm{G}$ band technique, have added a new dimension to the study of human chromosomes. The application of new techniques to human subjects with various congenital anomalies has sometimes revealed significant relationships between chromosomal mutations and disease. Such anomalies of the sex chromosomes, trisomy or partial monosomy for one member of a group of autosomes were described in different syndromes. Recent techniques make it possible to study chromosomes in various arrangements, in their balanced or unbalanced forms, and variations in the morphology of one homologue of a pair by comparison with the other (Battaglia et al., 1971). Friedreich's ataxia is usually inherited as an autosomal recessive. Some authors found it can be transmitted as an autosomal dominant (Bell and Carmichael, 1939). Skre (1975), as mentioned by Lubozynski and Roelofs (1975) found that later maternity (over 34 years old) was significant for the manifestation of disease in Friedreich's ataxia, cerebellar ataxia and Charcot-Marie-Tooth disease. Samad et al. (1973) have found a significant number of chromosomal breakages in cells from a patient with Friedreich's ataxia and hypoplastic anemia.

\section{MATERIAL AND METHODS}

Out of 36 cases of typical Friedreich's ataxia, 16 were studied using $\mathrm{Q}$ and $\mathrm{G}$ banding techniques. Also out of 14 cases of atypical re- cessive ataxia, 3 cases were studied with the same techniques. Chromosomal rearrangements as well as gaps and breaks were also evaluated.

There were 5 men and 11 women in the group with typical Friedreich's ataxia. Their ages were from 8 to 35 , with a mean of 25 years. Three cases of atypical recessive ataxia were also studied; a man of 45 years and two women of 26 and 22. One culture failed.

Banding patterns of human chromosomes are revealed by different techniques:

Q-bands: using certain acridine derivatives

C-bands: by denaturating with $\mathrm{NaOH}$ and renaturating with sodium citrate

G-bands: by employing $\mathrm{NaOH}$ denaturation and Sörensen buffer and treatment with trypsin

R-bands: by employing a specific denaturation method

T-bands: by using Giemsa and orange acridine stains

Q-band and G-band techniques were used in our study. Chromosomes were obtained by a short term culture of lymphocytes with phytohemagglutinine. Air-dried chromosome preparations were fixed in methanol-acetic acid $(3: 1)$, put in phosphate buffer at pH 6.8 at $62^{\circ} \mathrm{C}$ for 24 hours. Subsequently, the slides were stained directly in a Giemsa solution. Some other slides were air-dried and stained $10 \mathrm{mi}-$ nutes with quinacrine $0.5 \%$, washed in running tap water and then put in a pH 5.5 buffer for 2 minutes. Each case was cultured with a control, usually a normal person working in the department of pathology. 
TABLE 1

Cytogenetic Findings in Friedreich's Ataxia

\begin{tabular}{lllllll}
\hline NO SEX AGE & \multicolumn{4}{c}{ CHROMOSOMES } & SEX & BREAKS \\
\cline { 3 - 5 } & & 44 & 45 & 46 & 47
\end{tabular}

\begin{tabular}{|c|c|c|c|c|c|c|c|c|}
\hline \multicolumn{9}{|c|}{ FRIEDREICH'S ATAXIA } \\
\hline 1 & $\mathrm{M}$ & 22 & - & - & 20 & - & $X Y$ & - \\
\hline 2 & $\mathrm{M}$ & 21 & - & - & 16 & - & $X Y$ & - \\
\hline 3 & $\mathrm{~F}$ & 25 & - & - & 20 & - & $X X$ & - \\
\hline 4 & $\mathrm{~F}$ & 21 & - & 1 & 19 & - & $x X$ & - \\
\hline 5 & $\mathrm{~F}$ & 35 & - & - & 21 & - & $X X$ & 1 \\
\hline 6 & $\mathrm{M}$ & 26 & - & - & 20 & - & $X Y$ & 1 \\
\hline 7 & $\mathrm{~F}$ & 8 & 1 & 1 & 18 & - & $x x$ & - \\
\hline 8 & $F$ & 32 & - & - & 20 & - & $X X$ & - \\
\hline 9 & $\mathrm{~F}$ & 27 & - & - & 17 & - & $X X$ & - \\
\hline 10 & $M$ & 25 & - & 7 & 22 & 1 & $X Y$ & 3 \\
\hline 11 & $\mathrm{M}$ & 27 & - & - & 20 & - & $X Y$ & - \\
\hline 12 & $\mathbf{F}$ & 25 & - & - & 20 & - & $X X$ & - \\
\hline 13 & $\mathrm{~F}$ & 23 & 1 & - & 15 & - & $X X$ & - \\
\hline 14 & $\mathrm{~F}$ & 32 & - & - & 20 & - & $X X$ & - \\
\hline 15 & $\mathrm{~F}$ & 30 & - & 1 & 19 & - & $x X$ & - \\
\hline \multicolumn{9}{|c|}{ ATYPICAL RECESSIVE ATAXIA } \\
\hline 16 & $\mathrm{M}$ & 48 & - & 1 & 32 & - & $X Y$ & 1 \\
\hline 17 & $\mathrm{~F}$ & 26 & - & - & 40 & - & $x X$ & 3 \\
\hline 18 & $\mathrm{~F}$ & 22 & - & 4 & 36 & - & $x \mathrm{X}$ & 1 \\
\hline
\end{tabular}

\section{RESULTS}

Out of 15 cases of Friedreich's ataxia analyzed, no one showed any chromosome anomalies. The routine stains as well as $Q$ and $G$ band stains failed to show any morphological anomalies. The numbers of breaks are shown in Table 1. In one case (No. 10), 7 hypodiploid cells with 45 chromosomes were counted, 22 diploid cells and one hyperdiploid cell with 47 chromosomes. Three breaks were also found in this case. Two other cases of Friedreich's ataxia

showed one break. The three cases of atypical recessive ataxia revealed one break in cases 16 and 17 and two breaks in case 18 . The sex chromosomes always conformed to phenotypic sex.

\section{DISCUSSION}

An increased incidence of chromosomal abnormalities might be expected in individuals with neurological malformations. This does not seem to be the case in neurological hereditary diseases. We did not expect to find chromosome abnormalities in Friedreich's ataxia and very careful studies confirm our suspicion. No significant difference was found in frequency of breakages or polyploidy between patients with ataxia and controls.

\section{ACKNOWLEDGMENTS}

These studies were supported by the Association Canadienne de l'Ataxie de Friedreich, la Fondation Jeanne-Mance de l'HôtelDieu de Montréal and the Medical Research Council of Canada.

\section{REFERENCES}

BATTAGLIA, E., GUANTI, G., BARSANTI, P., and PETRINELLI, P. (1971). Chromosomal survey in 298 normal subjects and 1,253 cases of congenital disorders during 1966-1970. Acta Genet. Med. (Roma), 20, 123-173.

BELL, J., and CARMICHAEL, E. A. (1939). On hereditary ataxia and spastic paraplegia. In: Treasury of Human Inheritance, Vol. 4, Cambridge University Press, (Fisher, R. A., ed.), pp. 141-281.
CASPERSSON, T., ZECH, L., JOHANSSON, C., and MODEST, E. J. (1970). Identification of human chromosomes by DNA-binding fluorescent agents. Chromosoma (Berl.), 30, 215-227.

LUBOZYNSKI, M. F., and ROELOFS, R. I. (1975). Friedreich's ataxia. Sth. Med. J., 68, 757-763.

SAMAD, F. U., ENGEL, E., and HASTMANA, R. C. (1973). Hypoplastic anemia, Friedreich's ataxia and chromosomal breakage. Case report and review of similar disorders. Sth. Med. J., 66, 135-140.

SKRE, H. (1975). Friedreich's ataxia in Western Norway. Clin. Genet., 7 (4), 287-298. 